\title{
Pubertal Growth and Final Height in Hypopituitary Boys: A Minor Role of Bone Age at Onset of Puberty*
}

\author{
JEAN-PIERRE BOURGUIGNON, MARK VANDEWEGHE, \\ MAGDA VANDERSCHUEREN-LODEWEYCKX, PAUL MALVAUX, RENÉE WOLTER, \\ MARC DU CAJU, AND CHRISTIAN ERNOULD \\ Belgian Study Group for Pediatric Endocrinology, Departments of Pediatrics, Universities of Liège (J.-P.B., \\ C.E.), Leuven (M.V.-L.), Louvain (P.M.), Brussels (R.W.), and Antwerp (M.D.C.); and the Department of \\ Endocrinology, University of Ghent (M.V.), Belgium
}

\begin{abstract}
Twenty-two hypopituitary boys treated with human GH were studied longitudinally before and during puberty. Eight patients entered spontaneous puberty at a mean bone age of $12.4 \pm 1.0( \pm \mathrm{SD}) \mathrm{yr}$. Height velocity reached a mean peak of $6.8 \mathrm{~cm} / \mathrm{yr}$ during the second year of spontaneous puberty. In these patients, the mean total height gain throughout puberty was $22.8 \pm 5.2 \mathrm{~cm}$, and the mean final height was $158.6 \pm 7.2$ $\mathrm{cm}$. Fourteen patients received testosterone enanthate $(100 \mathrm{mg} /$ month, im) starting at a mean bone age of $13.6 \pm 1.1 \mathrm{yr}$. Height velocity was maximal $(7.5 \mathrm{~cm} / \mathrm{yr})$ during the first year of therapy. The mean final height was $162.9 \pm 5.0 \mathrm{~cm}$, with a mean pubertal gain of $15.9 \pm 3.8 \mathrm{~cm}$. Genital development, peak height velocity, and increase in plasma testosterone levels occurred earlier during testosterone therapy than during spontaneous puberty. In both groups of patients, there was a positive correlation between the bone age at onset of puberty and the height at onset of
\end{abstract}

puberty $(r=0.65)$. There was also a negative correlation between bone age and total pubertal height gain $(r=-0.73)$. This reduction in pubertal height increase was less than expected for bone age at onset of puberty, which can be explained by a decrease in bone age velocity in relation to bone age at onset of puberty $(r=-0.81)$. Therefore, advancement in bone age at the onset of testosterone therapy did not impair final height, whereas it may increase height at onset of puberty, which is the major factor in final height.

We conclude that in GH- and gonadotropin-deficient boys 1) a reduced dosage of testosterone enanthate $(25 \mathrm{mg}$ twice a month, im) should be used to induce pubertal development, and 2) the major criterion to decide when to give testosterone is height reached at that time regardless of bone age. ( $J$ Clin Endocrinol Metab 63: 376, 1986)
$\mathrm{M}$ OST hypopituitary patients have multiple hormone deficiencies, including $\mathrm{GH}$ and gonadotropin deficiencies. In males, treatment with both androgens and human $\mathrm{GH}(\mathrm{hGH})$ is required to induce a pubertal growth spurt (3-8). Although some patients may reach a satisfactory final height, the optimal dosage of testosterone and the best age to begin androgen therapy are not known. The available data suggest that during androgen therapy, the growth spurt might depend on the age at which treatment was begun (9-14). However, no systematic study on this issue has been reported. The aim of this study was to analyze height velocity and final stature in hypopituitary patients in relation to bone age at onset of puberty and to evaluate the effects of testosterone treatment compared with the course of spontaneous puberty in hypopituitary boys.

Received October 22, 1985 .

Address requests for reprints: Dr. J. P. Bourguignon, Pediatric Clinic, Hôpital de Bavière, B 4020 Liège, Belgium.

* Parts of this work $(1,2)$ were presented at the Seventh International Congress of Endocrinology, Quebec, Canada, July 1984, and at the Second Joint Meeting of Lawson Wilkins Pediatric Endocrine Society and the European Society for Paediatric Endocrinology, Baltimore, MD, June 1985.

\section{Subjects and Methods}

\section{Patients}

Twenty-two hypopituitary boys were studied longitudinally. At the time of diagnosis, all had a height velocity below the third percentile according to Tanner (15). The criteria to diagnose GH deficiency and the management of the other pituitary hormone deficiencies were described previously (16). The patients were divided into two groups: boys with spontaneous puberty $(n=8)$ and boys with gonadotropin deficiency $(n=$ 14). In the latter group, pubertal development was induced by giving testosterone enanthate (Testoviron-depot, Schering, Bloomfield, NJ; $100 \mathrm{mg} /$ month, im). The biological features of gonadotropin deficiency and the criteria used to start testosterone administration also were reported previously (16). Briefly, the criteria were 1) the absence of any sign of puberty and a decrease in height velocity (despite hGH treatment) when bone age was $11.5 \mathrm{yr}$ or greater, 2) a serum $\mathrm{LH}$ response to $\mathrm{GnRH}$ $\left(25 \mu \mathrm{g} / \mathrm{m}^{2}\right)$ that was low for bone age, and 3) request by the patient.

All patients were treated with hGH (Crescormon, Kabi, Stockholm, Sweden) throughout the study period. hGH was given as an evening im injection of $6 \mathrm{IU}$, three times weekly. This dosage was not changed during testosterone therapy, 
whereas it was increased up to $8 \mathrm{IU} /$ injection at the time when signs of spontaneous puberty were observed. The mean chronological age at the beginning of hGH therapy was not significantly different between boys with gonadotropin deficiency $[14.3 \pm 3.6( \pm \mathrm{SD}) \mathrm{yr}]$ and those who entered spontaneous puberty $(12.7 \pm 2.8 \mathrm{yr})$.

When puberty occurred during the first year of hGH therapy, the data were not included in the study to exclude possible catch-up of height velocity due to hGH itself $(7,12,17-20)$. Treatment with hGH was stopped when height velocity declined to less than $2 \mathrm{~cm}$ for the previous 6 months. Patients with incomplete spontaneous puberty were excluded from this study.

Informed consent was obtained from all patients and from their parents. This investigation was completed before Creutzfeldt-Jacob disease was reported to occur in some patients previously treated with hGH (21). Since that time, the use of extractive pituitary GH has been stopped in Belgium.

\section{Methods}

All patients were followed regularly in the pediatric departments of the different Belgian university hospitals, according to a single well defined protocol. Every 3 months, height was measured using the Harpenden stadiometer. Genital and pubic hair development were estimated according to the five stages of Tanner (22). Testicular volume was measured using the orchidometer of Prader (23). Plasma testosterone and dehydroepiandrosterone sulfate concentrations were measured by specific RIAs. During testosterone therapy, blood samples were obtained about 2 weeks after the last injection. Adrenarche was considered to be absent when plasma levels of dehydroepiandrosterone sulfate were below $200 \mathrm{ng} / \mathrm{ml}$ in patients whose bone age was greater than $11 \mathrm{yr}$ (16). The onset of spontaneous puberty was defined as the time of the last examination before a testicular volume above $3 \mathrm{ml}$ was found. In gonadotropindeficient patients, the time of onset of puberty was considered to be the first day of testosterone administration.

Bone age was measured once a year before puberty and twice a year during puberty by a single examiner according to the $\mathrm{TW}_{2}$ method of Tanner et al. (24), rating 20 bones of the hand and wrist. Height age and height gain expected for bone age were calculated with reference to the 50th percentile of height according to the method of Tanner and Whitehouse (25). Ages were expressed in years and decimal fractions thereof. The sexcorrected midparental height, also called target height, was calculated according to the procedure of Tanner et al. (26). In male patients, target height is obtained by adding $6.5 \mathrm{~cm}$ to the arithmetic mean of the parent's height.

\section{Statistical analysis}

The significance of differences between the two groups of patients were calculated using Student's $t$ test. When correlations were studied, their significance was determined from the variance, and the regression lines were compared (27). Differences were considered to significant at $P<0.05$.

\section{Results}

\section{Clinical features of the two groups of patients}

Table 1 shows the clinical data on the patients with spontaneous and testosterone-induced puberty. All were assumed to have idiopathic hypopituitarism. Among the 8 patients with spontaneous puberty, 4 had associated TSH deficiency. All 14 patients with gonadotropin deficiency had TSH deficiency, 8 of them had ACTH deficiency, and 9 no adrenarche. The mean sex-corrected midparental height (or target height) was not significantly different in the 2 groups of patients. The mean chronological age, bone age, height age, and height were significantly higher in those patients in whom testosterone had to be given than in those entering spontaneous puberty.

\section{Pubertal score, height velocity, and bone maturation before and during puberty}

As shown in Fig. 1, spontaneous and testosteroneinduced puberty resulted in similar changes. The final stages of genital score and pubic hair score were reached by an increasing number of patients, height velocity and bone maturation accelerated, and plasma testosterone levels increased. However, some differences were found between the two groups of patients. After 1 yr of pubertal development, the genital score was stage 4 or 5 in $47 \%$

TABLE 1. Relevant clinical data on 22 hypopituitary boys at the time of spontaneous or induced puberty

\begin{tabular}{lcc}
\hline & $\begin{array}{c}\text { Spontaneous } \\
\text { puberty }\end{array}$ & $\begin{array}{c}\text { Testosterone- } \\
\text { induced puberty }\end{array}$ \\
\hline Total no. of patients & 8 & 14 \\
Pituitary deficiencies & $8 / 8$ & $14 / 14$ \\
GH & $4 / 8$ & $14 / 14$ \\
TSH & $0 / 8$ & $14 / 14$ \\
FSH-LH & $0 / 8$ & $8 / 14$ \\
ACTH & $0 / 8$ & $9 / 14$ \\
Absence of adrenarche & $169.2 \pm 4.0$ & $170.8 \pm 7.5^{a}$ \\
Mean sex-corrected mid- & & \\
parental (target) ht & & \\
$\quad$ (cm) & & \\
Age (yr) at onset ${ }^{b}$ of pu- & & $18.5 \pm 1.7^{c}$ \\
$\quad$ berty & $15.0 \pm 1.2$ & $13.6 \pm 1.1^{d}$ \\
Chronological age & $12.4 \pm 1.0$ & $146.1 \pm 1.0^{c}$ \\
Bone age & $10.1 \pm 1.3$ & \\
Ht age & $135.8 \pm 5.6$ & \\
Ht (cm) at onset ${ }^{b}$ of pu- & & \\
berty & &
\end{tabular}

Values are the mean \pm SD.

${ }^{a} P=$ NS us. spontaneous puberty.

${ }^{b}$ Onset of puberty for boys with spontaneous puberty was the last 3 month visit before testicular volume greater than $3 \mathrm{ml}$ was found; for boys with induced puberty onset was considered to occur at the start of testosterone enanthate treatment ( $100 \mathrm{mg} / \mathrm{month}, \mathrm{im})$.

${ }^{c} P<0.001$ vs. spontaneous puberty.

${ }^{d} P<0.05$ us. spontaneous puberty. 


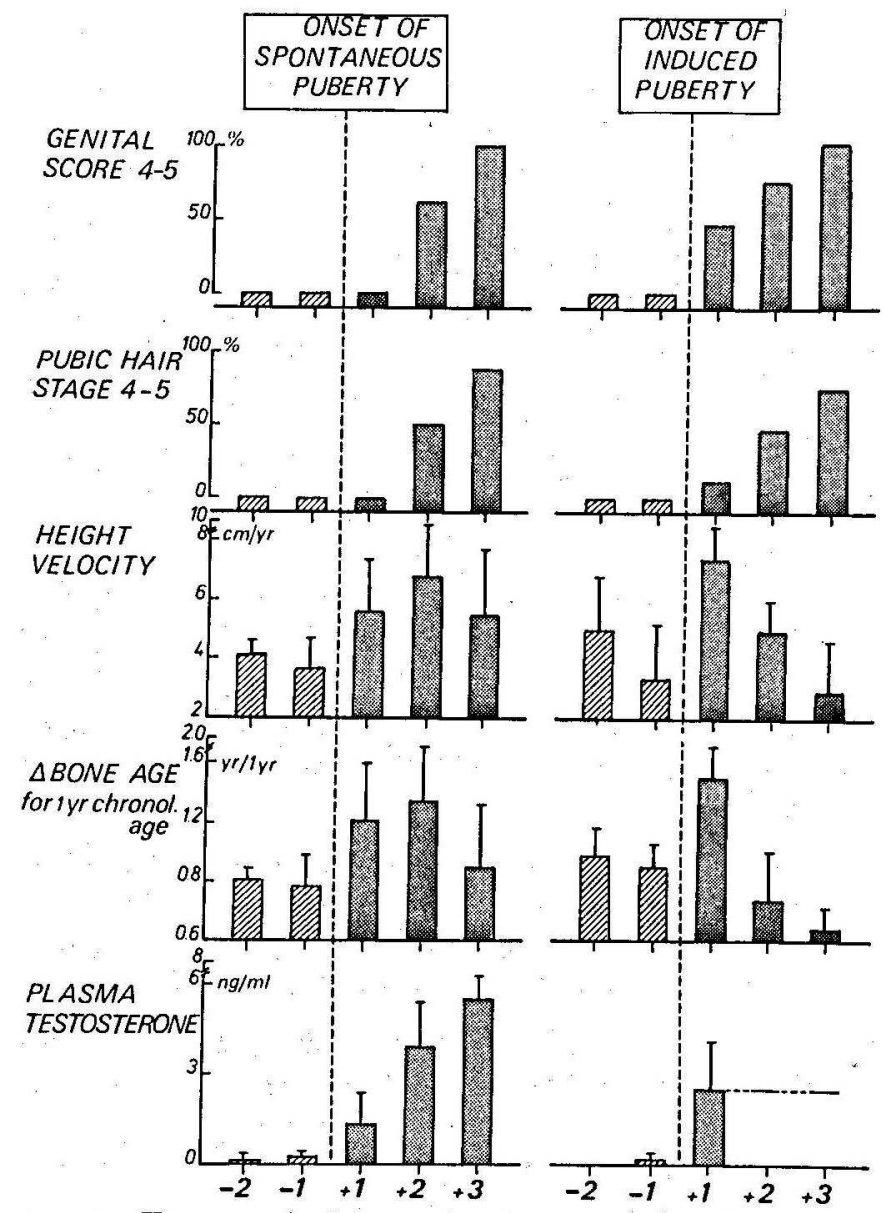

Time (yrs) before $(-1)$ \& after(t)onset of puberty

FIG. 1. Mean $( \pm S D)$ genital score, pubic hair development (stages 4 and 5 according to Tanner), height velocity, bone maturation, and plasma testosterone levels in relation to time before and during spontaneous or testosterone-induced puberty in hypopituitary boys. The dashed line indicates that during induced puberty, mean plasma testosterone levels were similar during the 3 yr of therapy.

of the patients treated with testosterone but in none of the patients who had spontaneous puberty. In all patients receiving testosterone, peak height velocity occurred during the first year of therapy (mean, $7.5 \mathrm{~cm} / \mathrm{yr}$ ). Spontaneous puberty resulted in a similar peak height velocity (mean, $6.8 \mathrm{~cm} / \mathrm{yr}$ ), although it occurred during the second year. Mean total height gain was $22.8 \pm 5.2( \pm \mathrm{SD}) \mathrm{cm}$ during spontaneous puberty and $15.9 \pm 3.8 \mathrm{~cm}$ during testosterone-induced puberty. The variations in bone maturation closely paralleled those in height velocity. During testosterone administration, the mean plasma testosterone level achieved $(2.5 \mathrm{ng} / \mathrm{ml})$ was significantly higher $(P<0.05)$ than that during the first year of spontaneous puberty $(1.3 \mathrm{ng} / \mathrm{ml})$ and lower $(P<0.01)$ than that during the third year of spontaneous puberty $(5.4 \mathrm{ng} / \mathrm{ml})$. The mean total duration of pubertal growth was $2.7 \pm 0.6( \pm \mathrm{SD})$ yr during testosterone treatment and $4.2 \pm 0.8$ yr during spontaneous puberty.

\section{Role of bone age at onset of puberty}

After spontaneous puberty, the mean final height was $158.6 \pm 7.2( \pm \mathrm{SD}) \mathrm{cm}$, whereas it was $162.9 \pm 5.0 \mathrm{~cm}$ in patients treated with testosterone. Among the 8 patients who entered puberty spontaneously, only 2 had a final stature above the third percentile of height. In contrast, 9 of 14 boys with gonadotropin deficiency had a final height above the third percentile.

In patients of both groups, final height was not significantly related to bone age at onset of puberty (Fig. 2 ). Height at onset of puberty was a direct function ( $\mathrm{r}=$ 0.65 ) of bone age at onset of puberty, whereas total pubertal height gain decreased significantly $(r=-0.73)$ in relation to bone age at onset of puberty. The correlations were not significantly different between patients with spontaneous puberty and those treated with testosterone. The velocity of bone maturation during puberty

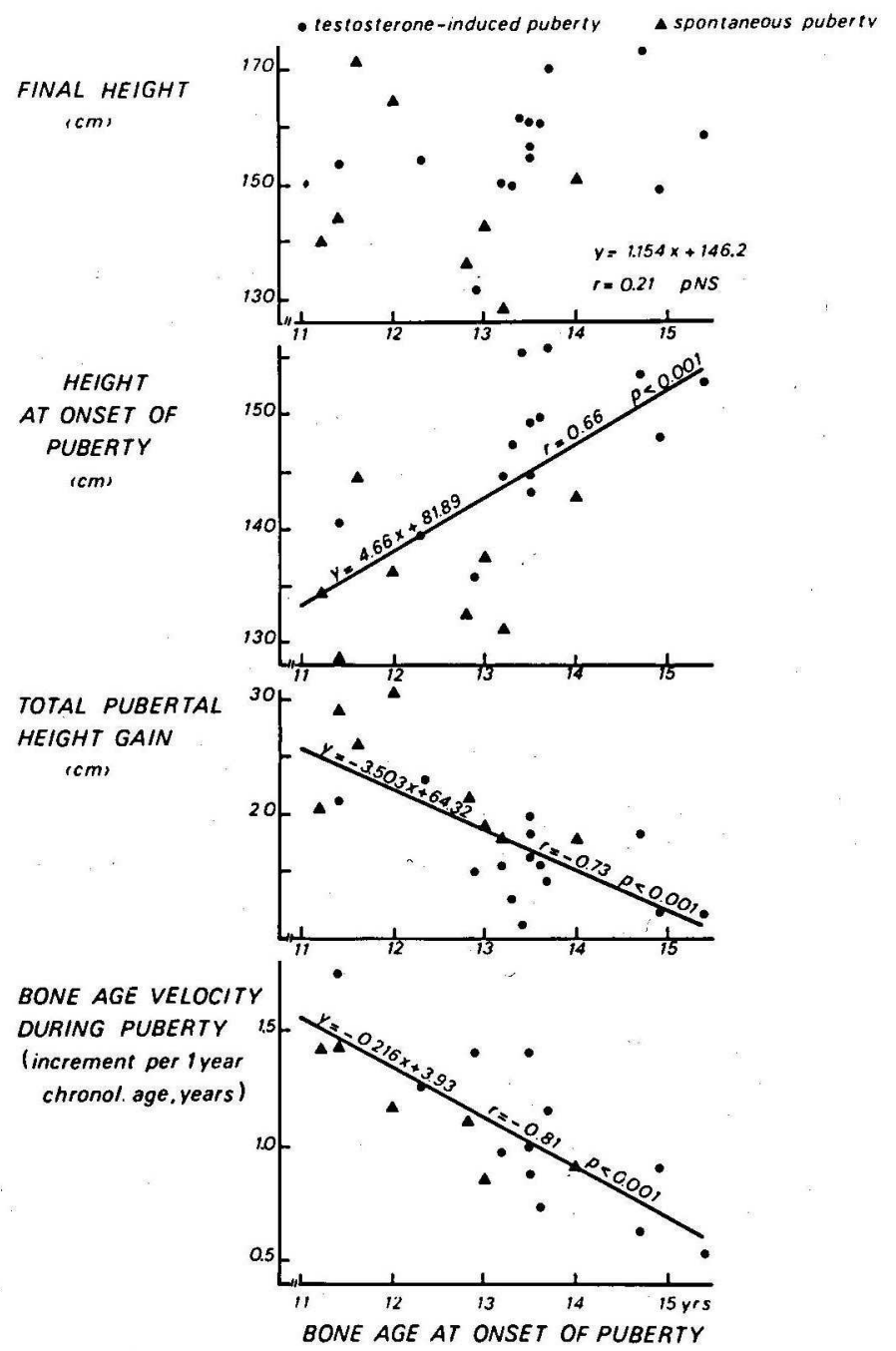

FIG. 2. Relationships between bone age at onset of puberty in hypopituitary boys and final height, height at onset of puberty, total pubertal height gain, and velocity of bone maturation during puberty. 
was calculated from the total increment in bone age during that period. In patients of both groups, a highly significant negative linear correlation ( $r=-0.81$ ) was found between velocity of bone maturation and bone age at onset of puberty (Fig. 2).

In Fig. 3 are illustrated the linear correlations between growth parameters and bone age at onset of testosterone therapy in gonadotropin deficient patients. These data are compared with the 50th centile of height for bone age in normal boys. According to the normal growth pattern, the progression of bone age results in an increase in height equivalent to the decrease in subsequent height gain so that a definite final height is reached. In hypopituitary boys, an increase in bone age at onset of testosterone treatment between 11 and $15 \mathrm{yr}$ results in a mean increase in height at that time $(+15.3 \mathrm{~cm})$ greater than the mean reduction in subsequent height gain $(-8.9 \mathrm{~cm})$. Therefore, as shown in Fig. 3, final height in testosterone-treated patients is slightly increased in relation to bone age $(+6.5 \mathrm{~cm})$. This difference may be explained by the low velocity of bone maturation during puberty in hypopituitary patients (Fig. 2).

\section{Factors important for final height}

As shown in the upper panel of Fig. 4, final height was a direct function of sex-corrected midparental height, also called target height $(r=0.57)$. Therefore, final height was analyzed as a percentage of target height to exclude the possible influence of individual genetic factors in the correlations studied. Final height was found to be positively related to height at onset of puberty $(r=0.66)$. In contrast, final height was not significantly related to height at onset of hGH therapy, duration of hGH therapy, or total pubertal height gain (Fig. 4).

\section{Discussion}

Our data provide the following original information concerning pubertal growth and final height in hypopituitary boys. 1) Monthly administration of $100 \mathrm{mg}$ longacting testosterone induced earlier acceleration in genital development and height velocity than did normal puberty. 2) Final height was not significantly related to bone age at onset of puberty, since an advanced bone age correlated with both an increase in height at onset of puberty and a decrease in the magnitude of the pubertal growth spurt. 3) An advanced bone age at onset of puberty resulted in a velocity of bone maturation slower than expected and subsequent height gain greater than expected. 4) Final height did not depend on pubertal growth, but it was related to height at onset of puberty. To facilitate the discussion, data from the literature are summarized in Table 2.

\section{Role of androgens in growth and pubertal development}

In hypopituitary boys with associated GH and gonadotropin deficiencies, peak height velocity could not be elicited by administration of testosterone alone $(3,4)$. In contrast, the combined administration of hGH and androgens induces satisfactory sexual development (except testicular enlargment) and acceleration in height velocity without disproportionate increase in bone maturation (1, $2,5,6,8)$. A still debated question is the dosage of
Fig. 3. Variations in height at onset of testosterone therapy, height gain during puberty, and final height of GH- and gonadotropin-deficient boys $(n=14)$ as a function of bone age at onset of testosterone therapy. From the slopes of the regression lines calculated between these parameters (upper panel), the diagram illustrates the variations in height when bone age at onset of testosterone increases from 11 to $15 \mathrm{yr}$ (lower panel). Data obtained at the 50 th centile of height in normal boys and thus, expected for bone age, are also shown.
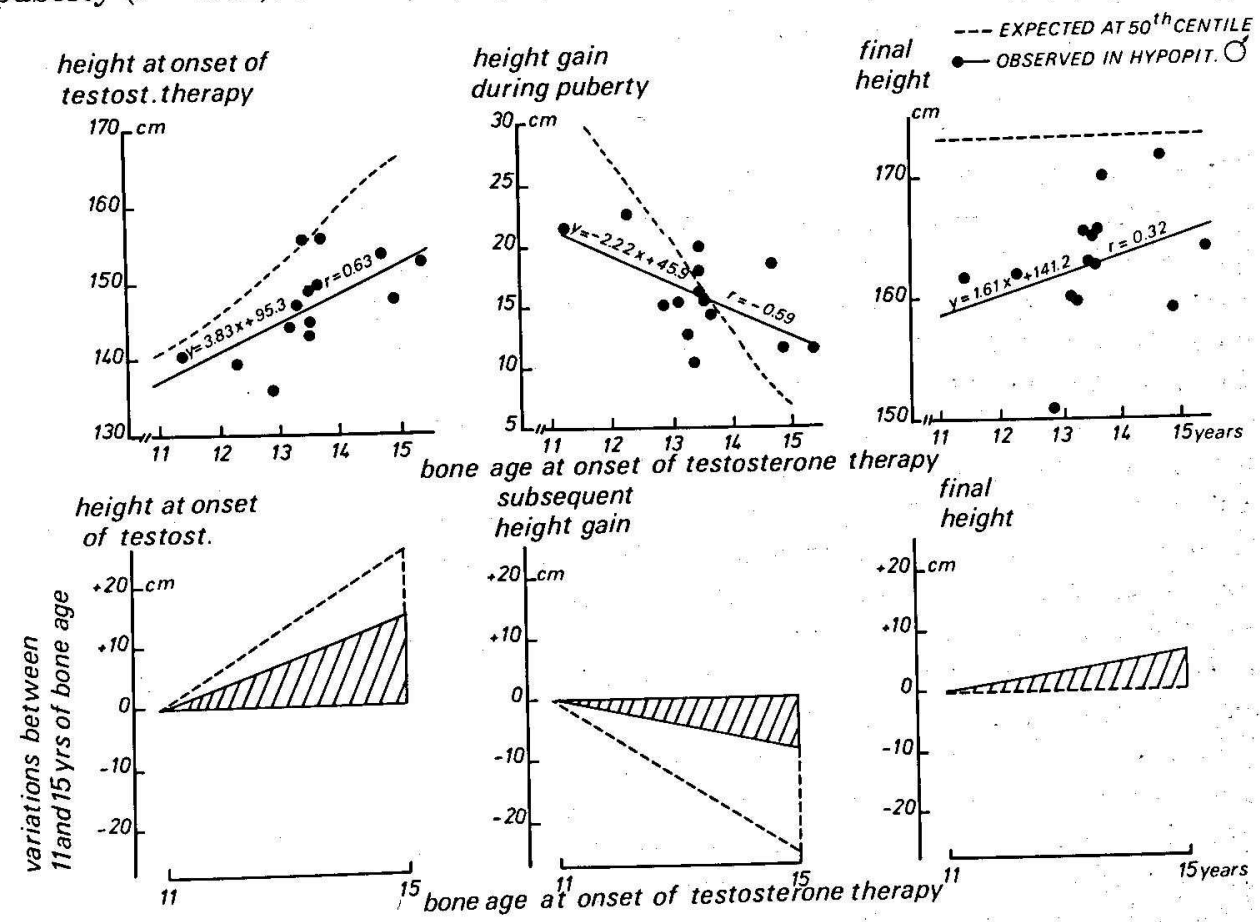


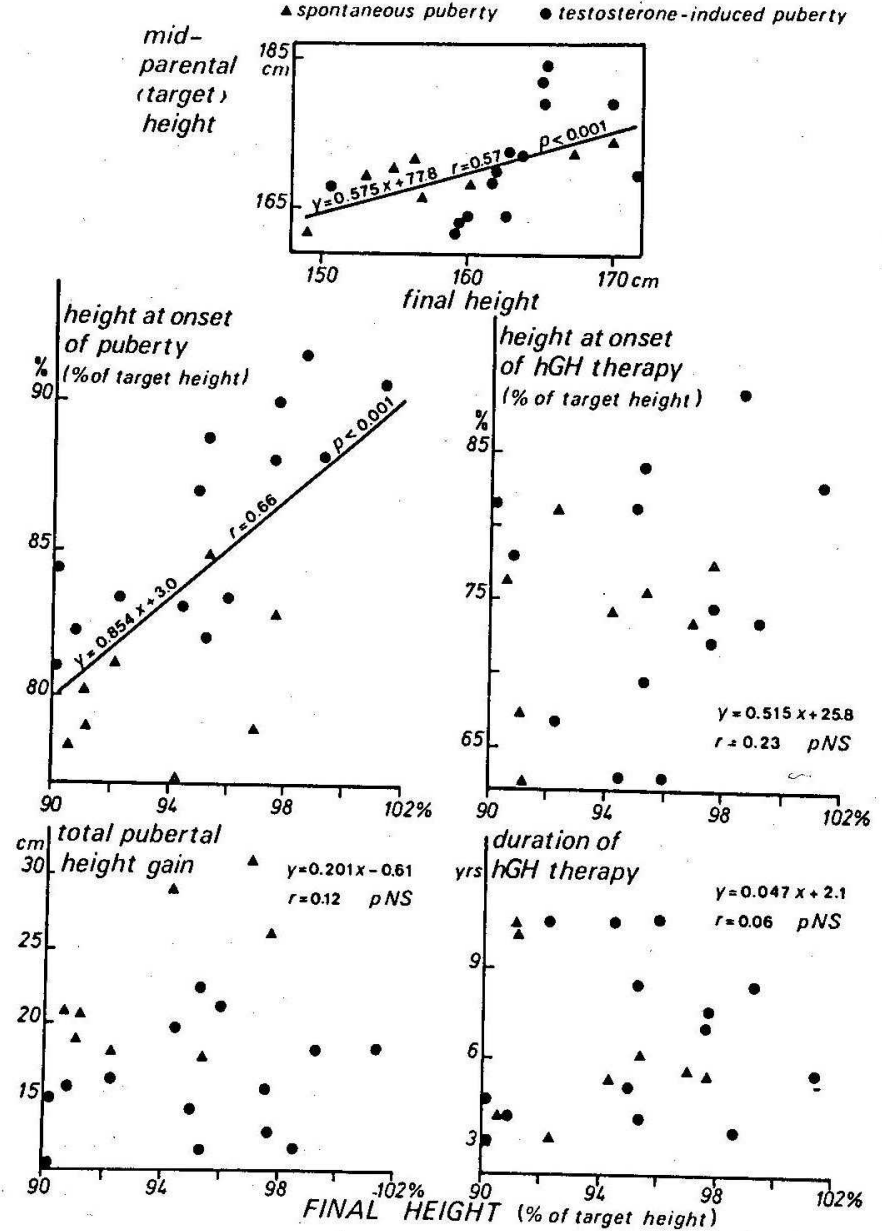

FIG. 4. Final height in GH-deficient boys is shown (upper panel) in relation to sex-corrected midparental height, also called target height. Final height as a percentage of target height is plotted against height at onset of puberty, height at onset of GH therapy, total pubertal height gain, and duration of GH therapy.

testosterone. Monthly injections of $250 \mathrm{mg}$ long-acting testosterone or more resulted in a precocious acceleration in height velocity $(3,5,6)$. More recently, most researchers (Table 2) used an initial testosterone dosage of 100 $\mathrm{mg} /$ month $(7,8,19,28)$, which was increased to $250 \mathrm{mg} /$ month after 3-12 months $(7,11,19,28)$. From our data, using $100 \mathrm{mg} / \mathrm{month}$, it would appear that such a low dosage was too high during the first year of therapy, as suggested by the early increase in plasma testosterone levels and the early occurrence of genital development and peak height velocity. Therefore, we suggest dosages of 50 and $100 \mathrm{mg} / \mathrm{month}$ for the first and second years of therapy, respectively. In addition, a recent study on testosterone dynamics (29) indicated that the monthly dosage should be given in divided doses every 2 weeks.

During spontaneous puberty in hypopituitary boys, the mean peak height velocity varied between 6.8 and 8.1 . $\mathrm{cm} / \mathrm{yr}(5,8,9,28)$, in agreement with the present findings. In our study, the mean total height gains throughout spontaneous and induced puberty were 22.8 and $15.9 \mathrm{~cm}$, respectively. These gains are somewhat higher than the mean height gains reported by Burns et al. (28), 17.0 and $10.4 \mathrm{~cm}$, respectively, but lower than the mean height gain of $27 \mathrm{~cm}$ in normal adolescents (10).

\section{Importance of hGH dosage for growth at puberty}

Several researchers emphasized the relationship between hGH dosage and growth response, particularly during the first year of hGH treatment $(7,12,20,30,31)$. The relation is exponential; a 2 -fold increase in hGH dosage results in a 1.2- to 1.4-fold increase in height velocity $(30,31)$. In the literature (Table 2$)$, the mean $\mathrm{hGH}$ dosages varied between 12 and $24 \mathrm{IU} /$ week during spontaneous puberty $(5,8,9,13,28)$ and between 12 and $20 \mathrm{IU} /$ week during testosterone therapy $(5-9,11,19,28)$. However, these different dosages did not influence the peak height velocity. In a preliminary study (8), using 12 IU hGH/week, we found a peak height velocity very similar to that in the present study where doses of 24 $\mathrm{IU} /$ week during spontaneous puberty and $18 \mathrm{IU} /$ week during testosterone therapy were used. Together with data obtained by others, our results suggest that hGH dosage should not be increased at the time of puberty.

\section{Bone age in relation to pubertal growth and final height}

The importance of the technique used to estimate bone age should be emphasized. In the literature (Table 2), most researchers used the method of Tanner et al. $\mathrm{TW}_{2}$ (24) because of its great accuracy. Since the occurrence of normal puberty is more closely linked to bone age than to chronological age, evaluation of bone age is critical for deciding when to give androgen therapy. In accordance with several researchers $(5,8,13,19,28)$, we found that spontaneous puberty occurred at a mean bone age of about $12.5 \mathrm{yr}$, whereas testosterone therapy began at a mean bone age of about $13.5 \mathrm{yr}$. However, in both groups of patients, the differences in bone age at onset of puberty did not significantly affect final height. This confirms the findings of Burns et al. (28) in hypopituitary boys. It appears that advancement in bone age at onset of puberty is associated with increased height at onset of puberty, but it reduces pubertal growth. However, when bone age at onset of puberty increased from 11 to $15 \mathrm{yr}$, the subsequent pubertal height gain was reduced much less than expected for bone age. Thus, advancement in bone age at onset of puberty is favorable to final height rather than prejudicial, as could be expected according to normal growth standards. Variations in velocity of bone maturation might account for those differences. Very little has been published on the velocity of bone age during puberty in hypopituitary patients. Milner and associates (17) found that bone maturation increased 
TARLE 2. Puberty in hypopituitary boys: summary of data from the literature

\begin{tabular}{|c|c|c|c|c|c|c|c|c|c|c|}
\hline \multirow[t]{2}{*}{ Ref. no. and authors } & \multirow[t]{2}{*}{$\begin{array}{l}\text { No. of } \\
\text { patients }\end{array}$} & \multicolumn{2}{|c|}{$\begin{array}{c}\text { Long-acting } \\
\text { testosterone } \\
\text { dosage (mg/ } \\
\text { month) } \\
\end{array}$} & \multirow[t]{2}{*}{$\begin{array}{c}\text { hGH } \\
\text { dosage } \\
\text { (IU/week) }\end{array}$} & \multirow{2}{*}{$\begin{array}{l}\text { Bone age } \\
\text { at onset } \\
\text { of } \\
\text { puberty } \\
\text { (yr) }\end{array}$} & \multirow{2}{*}{$\begin{array}{l}\text { Chronological } \\
\text { age at onset } \\
\text { of puberty } \\
\text { (yr) }\end{array}$} & \multirow[t]{2}{*}{$\begin{array}{c}\text { Peak } \\
\text { ht } \\
\text { velocity } \\
\text { (cm/yr) }\end{array}$} & \multirow[t]{2}{*}{$\begin{array}{l}\text { Total ht gain } \\
\text { after onset of } \\
\text { puberty }(\mathrm{cm})\end{array}$} & \multirow{2}{*}{$\begin{array}{l}\text { Chronological } \\
\text { age at onset } \\
\text { of hGH (yr) }\end{array}$} & \multirow[t]{2}{*}{$\begin{array}{l}\text { Mean final ht } \\
\text { (SD of 50th } \\
\text { percentile) }\end{array}$} \\
\hline & & Initial & $\begin{array}{c}\text { After } \\
0.3-1 \text { yr } \\
\end{array}$ & & & & & & & \\
\hline Spontaneous puberty & & & & & & & & & & 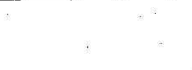 \\
\hline $\begin{array}{l}\text { 13) Tanner et al., } \\
1975\end{array}$ & 19 & & & 20 & $12.0^{c}$ & 15.0 & 8 & & & . \\
\hline $\begin{array}{l}\text { 5) Tanner et al., } \\
1976\end{array}$ & 6 . & & & 20 & & & 8.1 & & & \\
\hline $\begin{array}{l}\text { 9) Pertzelan et al., } \\
1979\end{array}$ & 7 & & & $12-18$ & $11 A^{c}$ & & 7.7 & & & \\
\hline $\begin{array}{l}\text { 8) Ernould et al., } \\
1980\end{array}$ & 4 & & & 12 & $11.4^{c}$ & 14.1 & 6.1 & & & . \\
\hline $\begin{array}{l}\text { 28) Burns et al., } \\
1981\end{array}$ & 11 & & & $15-20$ & $12.8^{c}$ & 15.9 & 7,8 & 17.0 & 11.3 & -2.3 \\
\hline Present study & 8 & & & 24 & $12.4^{c}$ & 15.0 & 6.8 & 22.8 & 12.7 & $-2 . \dot{5}$ \\
\hline $\begin{array}{l}\text { Testosterone-induced } \\
\text { puberty }\end{array}$ & & s. & & & . & & & & & \\
\hline $\begin{array}{l}\text { 5) Tanner et al, } \\
1976\end{array}$ & 2 & 250 & 250 & 20 & $13.3^{c}$ & & 7.6 & & & \\
\hline $\begin{array}{l}\text { 6) Aynsley-Green } \\
\text { et al., } 1976\end{array}$ & 12 & 151 & & 19.5 & $12.3^{b}$ & 17.8 & 8.0 & & & \\
\hline $\begin{array}{l}\text { 9) Pertzelan et al., } \\
1979\end{array}$ & 12 & $50-75$ & & $12-18$ & & & 6.5 & & & \\
\hline $\begin{array}{l}\text { 8) Ernould et al., } \\
1980\end{array}$ & 5 & 100 & 100 & 12 & $14.3^{c}$ & 19.0 & 7.2 & & & \\
\hline $\begin{array}{l}\text { 28) Burns et al., } \\
1981\end{array}$ & 6 & 100 & 250 & $15-20$ & $13.8^{c}$ & 20.4 & 7.4 & 10.4 & 14.9 & -1.5 \\
\hline $\begin{array}{l}\text { 11) Lenko et al., } \\
1982\end{array}$ & 10 & 50 & $150-250$ & 12 & . & & 7.6 & & 14.9 & -2.0 \\
\hline Present study & 14 & 100 & 100 & 18 & $13.6^{c}$ & 18.5 & 7.5 & 15.9 & & \\
\hline
\end{tabular}

${ }^{a}$ Standardized for $1.5 \mathrm{~m}^{2}$ body surface area.

${ }^{b}$ According to Greulich and Pyle (32).

${ }^{c}$ According to Tanner et al. (24).

about $1 \mathrm{yr}$ for every $1 \mathrm{yr}$ of chronological age regardless of bone age reached. However, these pàtients were not studied in relation to their pubertal development. During testosterone therapy in boys with craniopharyngioma, Burns et al. (10) reported a mean increase in bone age of $3.1 \mathrm{yr}$ during a mean period of $2.4 \mathrm{yr}$. We found, however, that the progression of bone age was related to bone age reached at onset of puberty. In fact, when puberty began at an early bone age, bone age velocity was faster than expected. In contrast, bone age velocity was slower than expected when puberty started at a late bone age. In the former situation, the pubertal growth spurt can be somewhat impaired, whereas in the latter condition, it is greater than expected for bone age at onset of puberty.

In summary, we conclude that in GH-deficient boys, the final height attained increases in relation to height at onset of puberty regardless of bone age at the time of puberty. Although administration of testosterone at an advanced bone age results in a slight reduction in pubertal height gain, there is also a marked decrease in bone age velocity, such that the final height is improved rather than impaired. According to these observations, we recommend the following management of $\mathrm{GH}$ - and gonadotropin-deficient boys. 1) Begin testosterone therapy when the optimal prepubertal height is reached regardless of bone age. In small boys whose increase in height velocity during $\mathrm{GH}$ is sustained, testosterone therapy can be delayed beyond a bone age of $14 \mathrm{yr}$ if psychologically acceptable. Such a delay will not markedly impair pubertal growth and may improve height at onset of puberty and, thus, final height. 2) A reduced dosage of testosterone enanthate, such as $25 \mathrm{mg}$ every. 2 weeks during the first year and $50 \mathrm{mg}$ every 2 weeks during the second year, should be used to induce pubertal development.

\section{Acknowledgments}

We are grateful to Prof. R. Eleckels, president of the National Committee for Treatment of GH Deficiency, for his stimulatory comments and criticism. We appreciated helpful discussions with Drs. G. 
Van Vliet and M. Craen. We are indebted to the Ministery of Health for providing the patients with hGH therapy. We thank Mrs. M. Beyer and $Y$. Vos de Wael for preparing the illustrations and the manuscript.

\section{References}

1. Vandeweghe M, Ernould C, Bourguignon JP 1984 Height velocity and bone maturation before and during spontaneous and testosterone-induced puberty in hGH treated hypopituitary boys. in: Abstracts of the 9th International Congress of Endocrinology. Excerpt Med Int Congr Ser 652 Excerpta Medica, Amsterdam, p 1467

2. Bourguignon JP, Vandeweghe $M$, Vanderschueren-Lodeweyckx $M$, Malvaux P, Wolter R, Du Caju M, Ernould Chr 1985 Pubertal growth and final height in hypopituitary boys are not related to bone age at onset of puberty. Pediatr Res 19:607

3. Zachmann M, Prader A 1970 Anabolic and androgenic effect of testosterone in sexually immature boys and its dependency on growth hormone. J Clin Endocrinol Metab 30:85

4. Blizzard RM, Thompson RG, Baghdassarian A, Kowarski A, Migeon CJ, Rodriguez A 1974 The interrelationship of steroids, growth hormone and other hormones on pubertal growth. In: Grumbach MM, Grave GD, Mayer FE (eds) The Control of the Onset of Puberty. Wiley and Sons, New York, p 342

5. Tanner JM, Whitehouse RH, Hughes PCR, Carter BS 1976 Relative importance of growth hormone and sex steroids for the growth at puberty of trunk length, limb length and muscle width in growth hormone-deficient children. J Pediatr 89:1000

6. Aynsley-Green A, Zachmann M, Prader A 1976 Interrelation of the therapeutic effects of growth hormone and testosterone on growth in hypopituitarism. J Pediatr 89:992

7. Rolland A, Mugnier E, Rappaport R, Job JC 1980 Le traitement du nanisme hypophysaire par l'hormone de croissance humaine. Résultats avant et pendant la puberté. Arch Fr Pediatr 37:659

8. Ernould C, Bourguignon JP, Lambrechts L, Craen M, Du Caju M, Malvaux P, Van Vliet G, Wolter R, Vanderschueren-Lodeweyckx M 1980 Effects of spontaneous and testosterone-induced puberty on height velocity, bone maturation and pubertal development in boys with hypopituitarism during human growth hormone therapy. In: Cacciari E, Prader A (eds) Pathophysiolog of Puberty. Academic Press, London and New York, p 315

9. Pertzelan A; Adler-Bier M, Kauli R, Josefsberg Z, Grunebaum M, Horodniceanu Ch, Laron Z 1979 Linear growth in hypopituitary patients treated with hGH after age fifteen. Acta Paediatr Scand [Suppl] 277:69

10. Burns EC, Tanner JM, Preece MA, Cameron N 1981 Growth hormone treatment in children with craniopharyngioma: final growth status. Clin Endocrinol (Oxf) 14:587

11. Lenko HL, Leisti S, Perheentupa J 1982 The efficacy of growth hormone in different types of growth failure. An analysis of 101 cases. Eur J Pediatr 138:241

12. Frasier SD 1983 Human pituitary growth hormone (hGH) therapy in growth hormone deficiency. Endocr Rev 4:155

13. Tanner JM, Whitehouse RH 1975 A note on the bone age at which patients with true isolated growth hormone deficiency enter puberty. J Clin Endocrinol Metab 41:788
14. Job JC, Joab N, Toublanc JE, Canlorbe $\mathrm{P} 1984$ Résultats à terme des traitements par l'hormone de croissance humaine. Arch Fr Pediatr 41:477

15. Tanner JM, Whitehouse RH, Takaishi M 1965 Standards from birth to maturity for height, weight, height velocity and weight velocity: British children 1965. Arch Dis Child 41:454

16. Bourguignon JP, Vandérschueren-Lodeweyckx M, Wolter R, Malvaux P, Craen M, Du Caju MVL, Ernould C, Franchimont P 1982 Hypopituitarism and idiopathic delayed puberty: a longitudinal study in an attempt to diagnose gonadotropin deficiency before puberty. J Clin Endocrinol Metab 54:733

17. Milner RDG, Preece MA, Tanner JM 1980 Growth in height compared with advancement in skeletal maturity in patients treated with human growth hormone. Arch Dis Child 55:461

18. Kurtz F, Mugnier E, Roy MP, Rappaport R 1981 Le traitement par hormone de croissance humaine. Facteurs influençant la réponse des enfants atteints d'insuffisance somatotrophique. Arch Fr Pediatr 38:405

19. Joss E, Zuppinger K, Schwarz HP, Roten H 1983 Final height of patients with pituitary growth failure and changes in growth variables after long term hormonal therapy. Pediatr Res 17:676

20. Sablayrolles B, Sanz MT, Mas B, Dutau G, Rochiccioli P 1983 Résultats du traitement par l'hormone de croissance. A propos de trente et une observations d'insuffisance hypophysaire. Ann Pediatr 509:14

21. Anonymous 1985 Ban on growth hormone. Lancet $1: 1172$

22. Tanner JM 1962 Growth at Adolescence. Blackwell, Oxford

23. Zachmann M, Prader A, Kind HP, Hafliger H, Budliger H 1974 Testicular volume during adolescence. Cross-sectional and longitudinal studies. Helv Paediatr Acta 39:61

24. Tanner JM, Whitehouse RH, Marshall WA, Healy MJR, Goldstein H 1975 Assessment of Skeletal Maturity and Prediction of Adult Height. Academic Press, London and New York

25. Tanner JM, Whitehouse RH 1976 Clinical longitudinal standards for height, weight, height velocity, weight velocity and stages of puberty. Arch Dis Child 51:170

26. Tanner JM, Goldstein H, Whitehouse RH 1970 Standards for children's height at ages 2-9 years allowing for height of parents. Arch Dis Child 45:755

27. Gremy F, Salmon D 1969 Bases Statistiques pour la Recherche Médicale et Biologique. Dunod; Paris

28. Burns EC, Tanner JM, Preece MA, Cameron N 1981 Final height and pubertal development in 55 children with idiopathic growth hormone deficiency, treated for between 2 and 15 years with human growth hormone. Eur J Pediatr 137:155

29. Snyder PJ, Lawrence DA 1980 Treatment of male hypogonadism with testosterone enanthate. J Clin Endocrinol Metab 51:1335

30. Preece MA, Tanner JM, Whitehouse RH, Cameron N 1976 Dose dependence of growth response to human growth hormone in growth hormone deficiency. J Clin Endocrinol Metab 42:477

31. Frasier SD, Costin G, Lippe BM, Aceto T, Bunger PF 1981 A doseresponse curve for human growth hormone. J Clin Endocrinol Metab 53:1213

32. Greulich WW, Pyle SI 1959 Radiographic Atlas of the Skeletal Development of Hand and Wrist, ed 2. Stanford University Press, Stanford 